\title{
The Effect of Capital Structure on Company Financial Performance
}

\author{
Nini $^{1}$, Dina Patrisia ${ }^{2^{*}}$, Agus Nurofik ${ }^{3}$ \\ ${ }^{1,2}$ Universitas Negeri Padang, Indonesia \\ ${ }^{3}$ STIE Perdagangan, Indonesia \\ Inini03598@gmail.com, 2patrisiadina@yahoo.com, 3agsnin@gmail.com, *corresponding author
}

\begin{abstract}
This study aims to examine the effect of capital structure on the company's financial performance particularly in manufacturing companies listed on the Indonesia Stock Exchange for the 4 years period from 2014 to 2018. Capital structure is measured by Market Total Leverage (MTLEV), Market LongTerm Leverage (MLLEV) and Market Short-Term Leverage (MSLEV). On the other hand, the company's financial performance is measured by Return on Equity (ROE) and Price to Book Value (PBV). The populations in this study are manufacturing companies listed on the Indonesia Stock Exchange and the selection of samples was determined by purposive sampling method, with the final samples as many as 333 company-years. The type of data used is secondary data from IDX using multiple regression analysis methods. The results of the analysis show that the capital structure has negative and significant effect on the company's financial performance in each model.
\end{abstract}

Keywords: capital structure, company financial performance

\section{Pengaruh Struktur Modal Terhadap Kinerja Keuangan Perusahaan}

\begin{abstract}
Abstrak
Penelitian ini bertujuan untuk menguji pengaruh struktur modal terhadap kinerja keuangan perusahaan pada perusahaan manufaktur yang terdaftar di Bursa Efek Indonesia periode 2014-2018. Struktur modal diukur dengan Market Total Leverage (MTLEV), Market Long-Term Leverage (MLLEV) dan Market ShortTerm Leverage (MSLEV). Sementara kinerja keuangan perusahaan diukur dengan Return on Equity (ROE) dan Price to Book Value (PBV). Populasi pada penelitian ini adalah perusahaan manufaktur yang terdaftar di Bursa Efek Indonesia. Sampel ditentukan dengan metode purposive sampling, kemudian sampel akhir diperoleh sebanyak 333 perusahaan-tahun. Jenis data yang digunakan adalah data sekunder dari IDX dengan menggunakan metode analisis regresi berganda. Hasil analisis menunjukan bahwa struktur modal berpengaruh negatif dan signifikan terhadap kinerja keuangan perusahaan disetiap model.
\end{abstract}

Kata kunci: struktur modal, kinerja keuangan perusahaan

\section{INTRODUCTION}

The increasingly fierce competition conditions require companies to improve their performance in order to be able to compete in the entered industry. The company's performance shows the effectiveness and efficiency of the company in managing all its resources to carry out its activities. According to Fosu (2013), company performance shows the efficient use of company resources by managers. In line with this opinion, Masa'deh et al. (2018) state that company performance is a comparison of actual results with the output planned by an organization. In addition, Santos \& Brito (2012) argue that company 
performance is part of organizational effectiveness which includes operational and financial results. Performance in the perspective of financial results is known as financial performance.

One of the measurements of the company's financial performance is the company's ability to generate profits. The intended profit can be in the form of gross profit, operations or net income from activities carried out. The ability of a company to generate profits can also be related to the assets used to generate profits or from the sources of funds used. Thus, the ability to generate profits is also known as the ability to return the investment.

The company's financial performance is very important for the company, namely to measure, evaluate data and provide solutions to company finances in one period. For creditors, the company's financial performance is valuable as this will be used by creditors as a reference for rejecting or approving a proposed loan. Knowing this information will make the creditors to have confidence that the money they will or have lent has not fallen into the wrong hands. If the loan is approved, it means that the creditor is sure that the company is able to pay and repay the loan according to the mutually agreed period of time. For investors, the company's financial performance can be taken into consideration when investing in a company. In this study, company performance discussed focuses on financial performance as measured by the ratio of Return on Equity (ROE) and Price to Book Value (PBV).

One of the factors that affect the company's financial performance is the capital structure. The capital structure is a balance between debt and equity as a source of funding used for the company's operations. Cuong \& Nguyen Thi (2012); Le \& Phan (2017); Li, Niskanen \& Niskanen (2018) argue that the capital structure shows a company's source of funding for its assets in the form of a mixture of debt and equity. Furthermore, Fahmi (2014) states that the capital structure describes the company's financial proportion, namely the comparison between long-term debt and its own capital.

The theories underlying this research are trade-off theory and agency theory. The trade-off theory is a theory that considers the costs and benefits of debt financing, namely the cost of financial difficulties with tax savings. According to Park \& Jang (2013) the use of debt can save taxes due to interest costs borne by the company. However, on the other hand, the use of debt also creates costs of financial difficulties related to the payment of interest on the loan principal with impact on bankruptcy. Consequently the company must be able to determine the right level of debt by considering tax savings and the cost of financial difficulties.

According to the trade-off theory, the effect of capital structure on the company's financial performance is not linear. In the initial condition, the increase in debt causes an increase in tax benefits that outweighs the increase in the cost of financial distress to a certain level of debt. After that, the increase in debt will cause the increase in tax savings to be smaller than the increase in the cost of financial hardship. Kraus \& Litzenberger (1973); Myers (1984) states that this occurs because the company will exchange the benefits of tax savings with the cost of financial difficulties from debt financing to create an optimal capital structure and increase company profits. The capital structure will have a positive effect 
when the benefits of adding debt are greater than those of the costs. Conversely, the capital structure will have a negative effect if the cost of adding debt exceeds the benefits obtained from debt financing.

Agency theory is a theory that arises because of the separation of ownership from company management. This separation can lead to the interests of the owner (principle) not in line with the interests of the manager (agent). Managers as agents sometimes make decisions that are not in line with the increase in shareholder welfare, resulting in agency conflicts (Jensen \& Meckling, 1976). This conflict of interest can arise in decisions related to funding, investment or dividends. In funding decisions, Jensen (1986) states the high use of debt, making managers under pressure to invest in profitable projects to pay interest. Therefore, through reducing agency costs associated with managers and shareholders, debt can have a positive effect on company performance.

On the other hand, debt can have a negative effect on company performance. Myers (1977) states that the use of debt can result in agency costs between shareholders and creditors. Based on this theory, when a company has a high level of debt with a large profit level, the shareholders and creditors will bear the most benefit from the success of the company. Creditors will react to this by charging a higher interest rate for companies that have a larger proportion of debt in order to offset the risk of lower liquidity or investment.

This study aims to determine the effect of capital structure on the company's financial performance particularly in manufacturing companies listed on the Indonesia Stock Exchange for the 2014-2018 period. In this study, capital structure is measured by market value-based ratios, namely Market Total Leverage (MTLEV), Market Long-Term Leverage (MLLEV) and Market Short-Term Leverage (MSLEV). The difference between book valuebased capital structure and market value-based capital structure is Welch (2011) and states that book value-based capital structure cannot show equity financing options properly, as book value of equity is only a counterweight to the total assets and claims of these assets by creditors. Meanwhile, according to Welch (2004) market value-based capital structure can show the relative ownership of a company by creditors with shareholders which cannot be shown by a book value-based capital structure. Two control variables were used in this study, namely the ratio of growth and company size.

Based on the background above, this study focuses on capital structure using market value-based measures as conducted by Le \& Phan (2017). The previous researchers mostly examined the capital structure using financial statement-based measurements and still a little using market value-based measures. For that reason, researchers are interested in reexamining particularly the context of research in Indonesia.

The relationship between capital structure and company financial performance can have both positive and negative effects. According to Le \& Phan (2017) in particular, at low levels, debt can improve company performance through tax protection, reduce equity agency costs or inform better prospects. However, when the leverage is high enough, increasing the debt ratio can decrease the company's performance because the benefits of debt are overcome by debt costs including financial difficulties and debt agency costs. Margaritis \& Psillaki (2010) found that financial leverage has a positive effect on firm 
performance. Detthamrong et al. (2017) who examined corporate governance, capital structure and firm performance: Evidence from Thailand in which they found the research results showing that financial leverage is positively related to company performance. David \& Olorunfemi (2010) studied the impact of capital structure on firm performance in the case of the Nigerian Oil Industry and found a positive relationship. Shyu (2013) examined the ownership structure, capital structure, and performance of group affiliations: Evidence from Taiwan-affiliated group companies. The results showed that capital structure has a significant positive effect on performance in group affiliated companies. Fosu (2013) examines capital structure, product market competition, and firm performance in companies in South Africa. The results showed that leverage has a positive and significant effect on company performance. Abidin et al. (2014) examined the effect of capital structure, dividend policy and size on firm value. The results showed that the capital structure had a positive effect on firm value. On the other hand, Vithessonthi \& Tongurai (2015) found that financial leverage is negatively related to firm performance for a sample of companies in Thailand. Cai \& Zhang (2011) show that changes in corporate financial leverage negatively affect stock prices. Adekunle \& Kajola (2010) studied the impact of capital structure on firm financial performance and found that leverage has a negative impact on firm profitability. Sadeghian et al. (2012) investigated the relationship between capital structure and firm performance in Tehran and found a negative relationship. Le \& Phan (2017) who investigated the effect of capital structure on company performance in non-financial companies registered in Vietnam found negative and significant effect on company performance. Dawar (2014) investigated Agency Theory, Capital Structure, and Company Performance. The results showed that the capital structure is negative and significant towards company performance

Based on expert opinion and the results from previous research, the following hypothesis are then developed:

H1: Market Total Leverage (MTLEV) has a significant effect on company performance as measured by ROE.

H2: Market Long-Term Leverage (MLLEV) has a significant effect on company performance as measured by ROE.

H3: Market Short-Term Leverage (MSLEV) has a significant effect on company performance as measured by ROE.

H4: Market Total Leverage (MTLEV) has a significant effect on company performance as measured by PBV.

H5: Market Long-Term Leverage (MLLEV) has a significant effect on company performance as measured by PBV.

H6: Market Short-Term Leverage (MSLEV) has a significant effect on company performance as measured by PBV. 


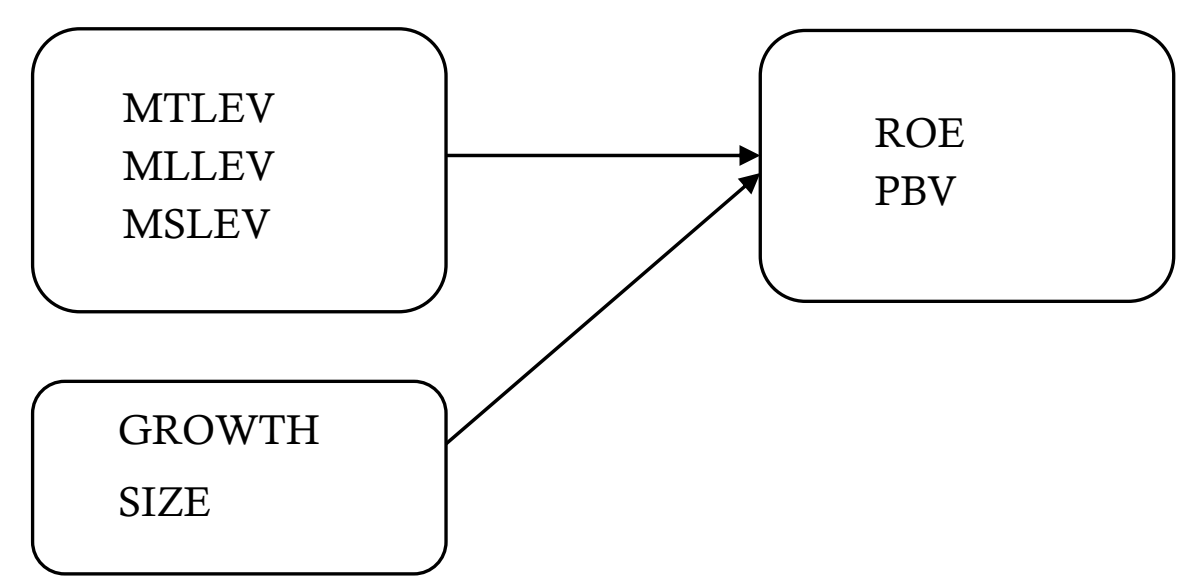

Figure 1. Research Model

\section{METHOD}

This research is a quantitative study and aims to analyze the influence between the independent variable and the dependent variable. This study collected data from the Indonesia Stock Exchange for the four -year- period from 2014 to 2018. The research samples were taken by using purposive sampling method, namely the sampling method based on certain criteria and considerations. The criteria for determining the sample are: 1) Manufacturing companies listed on the Indonesia Stock Exchange as issuers during the 2014-2018 periods. 2) Companies that did not experience delisting from the Indonesia Stock Exchange during the 2014-2018 periods. 3) Companies that consistently present complete data of financial report data for the 2014-2018 periods in Indonesian rupiah units and have complete data. 4) Companies with positive equity value from 2014-2018. The data were taken from the company's financial reports on the Indonesia Stock Exchange website. The size of final samples consisted of 333 companies during the 2014-2018 period.

This study uses multiple regression analysis with the following regression model:

$$
\begin{array}{ll}
\mathrm{ROE} & =\alpha+\beta_{1} \mathrm{MTLEV}+\beta_{2} \text { GROWTH }+\beta_{3} S I Z E+\epsilon . \\
\mathrm{ROE} & =\alpha+\beta_{1} \mathrm{MLLEV}+\beta_{2} \mathrm{MSLEV}+\beta_{3} \text { GROWTH } \\
\mathrm{PBV} & =\alpha+\beta_{1} \mathrm{MTLEV}+\beta_{2} \text { GROWTH }+\beta_{3} S I Z E+\epsilon . \\
\mathrm{PBV} & =\alpha+\beta_{1} \mathrm{MLLEV}+\beta_{2} \mathrm{MSLEV}+\beta_{3} \text { GROWTH } \\
\text { Information: } & \\
\alpha & =\text { Constant or Intercept } \\
\beta & =\text { Regression Coefficient } \\
\mathrm{ROE} & =\text { Return On Equity } \\
\mathrm{PBV} & =\text { Price to Book Value } \\
\mathrm{MTLEV} & =\text { Market Total Leverage } \\
\mathrm{MLLEV} & =\text { Market Long-Term Leverage } \\
\mathrm{MSLEV} & =\text { Market Short-Term Leverage } \\
\text { Growth } & =\text { Firm Growth } \\
\text { Size } & =\text { Firm Size } \\
\epsilon & =\text { Error }
\end{array}
$$$$
\mathrm{ROE}=\alpha+\beta_{1} \mathrm{MLLEV}+\beta_{2} \mathrm{MSLEV}+\beta_{3} \text { GROWTH }+\beta_{4} S I Z E+\epsilon \text {. }
$$$$
\mathrm{PBV}=\alpha+\beta_{1} \mathrm{MLLEV}+\beta_{2} \mathrm{MSLEV}+\beta_{3} \text { GROWTH }+\beta_{4} S I Z E+\epsilon .
$$ 
Jurnal Economia, 16(2), October 2020, 173-183

The definitions of the variables used in this study and their measurements can be seen in Table 1.

Table 1. Operational Definition and Variable Measurement

\begin{tabular}{|c|c|c|c|}
\hline Variable & $\begin{array}{l}\text { Operational } \\
\text { Definition }\end{array}$ & Proxy & Source \\
\hline \multicolumn{4}{|l|}{ Dependent: } \\
\hline \multirow{3}{*}{$\begin{array}{l}\text { Company } \\
\text { Financial } \\
\text { Performance }\end{array}$} & $\begin{array}{l}\text { Shows the } \\
\text { ability to use } \\
\text { resources } \\
\text { efficiently }\end{array}$ & $\mathrm{ROE}=\frac{\text { Net profit }}{\text { Total Equity }} \times 100$ & $\begin{array}{l}\text { Le \& Phan } \\
\quad(2017)\end{array}$ \\
\hline & & Market Price Per Share & Fischer \\
\hline & $\begin{array}{l}\text { the company's } \\
\text { ability to } \\
\text { generate net } \\
\text { profit for its } \\
\text { shareholders }\end{array}$ & PBV $=\overline{\text { Book Value Per Share }}$ & $(2007)$ \\
\hline \multicolumn{4}{|c|}{$\begin{array}{l}\text { Independent } \\
:\end{array}$} \\
\hline \multirow{4}{*}{$\begin{array}{l}\text { Capital } \\
\text { Structure }\end{array}$} & \multirow{4}{*}{$\begin{array}{l}\text { The balance } \\
\text { between the } \\
\text { capital } \\
\text { originating } \\
\text { from the } \\
\text { creditors and } \\
\text { the total } \\
\text { capital based } \\
\text { on market } \\
\text { value }\end{array}$} & MTLEV $=\frac{\text { Total debt }}{\text { Total debt }+ \text { Market value of common stock }} \times 100$ & $\begin{array}{l}\text { Le \& Phan } \\
\quad(2017)\end{array}$ \\
\hline & & MLLEV $=\frac{\text { Long term debt }}{x 100}$ & Le \& Phan \\
\hline & & MLLEV $=\overline{\text { Total debt }+ \text { Market value of common stock }} \times 100$ & (2017) \\
\hline & & MSLEV $=\frac{\text { Shot term debt }}{\text { Total debt }+ \text { Market value of common stock }} \times 100$ & $\begin{array}{l}\text { Le \& Phan } \\
\quad(2017)\end{array}$ \\
\hline \multicolumn{4}{|l|}{ Control: } \\
\hline \multirow[t]{2}{*}{ Growth } & \multirow{2}{*}{$\begin{array}{l}\text { Company } \\
\text { growth as } \\
\text { measured by } \\
\text { the growth of } \\
\text { the company's } \\
\text { assets. }\end{array}$} & \multirow{2}{*}{ Growth $=\frac{\text { Total Asset }(\mathrm{t})-\text { Total Asset }(\mathrm{t}-1)}{\text { Total Asset }(\mathrm{t}-1)} \times 100$} & \multirow{2}{*}{$\begin{array}{l}\text { Dawar } \\
(2014)\end{array}$} \\
\hline & & & \\
\hline Size & $\begin{array}{l}\text { Shows the } \\
\text { size of the } \\
\text { company } \\
\text { based on the } \\
\text { company's } \\
\text { assets. }\end{array}$ & Size $=\log ($ Total Aset $)$ & $\begin{array}{l}\text { Kieschnick } \\
\quad \& \\
\text { Moussawi } \\
(2018)\end{array}$ \\
\hline
\end{tabular}

Source: From various articles

\section{RESULTS AND DISCUSSION}

Based on the results of the descriptive statistical test in Table 2, it can be seen that there are 333 companies during the 2014-2018 period as the final samples of the study. Then from Table 2, it can be seen an overview of the variables to be analyzed in this study. For more details, each variable is listed in the following table 2 . 
The average value of ROE is 7.27 , while the average PBV value is 1.79 . The average value of Market Total Leverage (MTLEV) is 41.43, then the average value of Market LongTerm Leverage (MLLEV) is 11.34 and the average value of Market Short-Term Leverage (MSLEV) is 30, 28. The average value of growth is 8.18 and the average value of Size is 12.27

Table 2. Descriptive Statistics Test Results

\begin{tabular}{lrrrrr}
\hline \multicolumn{1}{c}{ Variabel } & N & Minimum & Maximum & Mean & $\begin{array}{c}\text { Std. } \\
\text { Deviation }\end{array}$ \\
\hline ROE & 333 & -21.04 & 35.61 & 7.2727 & 10.17382 \\
PBV & 333 & -3.19 & 6.79 & 1.7933 & 1.78909 \\
\hline MTLEV & 333 & 2.21 & 93.90 & 41.4342 & 26.13756 \\
MLLEV & 333 & 0.19 & 54.40 & 11.3366 & 11.90203 \\
MSLEV & 333 & 1.02 & 90.60 & 30.2846 & 21.99993 \\
\hline GROWTH & 333 & -47.00 & 64.70 & 8.1768 & 14.35138 \\
\hline SIZE & 333 & 10.99 & 14.54 & 12.2680 & 0.67213 \\
\hline Valid N (listwise) & 333 & & & \\
\hline
\end{tabular}

Before using the regression model, this research has passed the classic assumption test, namely, Normality Test, Multicollinearity Test, Heteroscedasticity Test, Autocorrelation Test, F Test, R2 Test and t Test. Based on the results of this study, all tests have been passed. The following shows the test results in Table 3.

Table 3. Analysis Test Results

\begin{tabular}{|c|c|c|c|c|c|c|c|c|}
\hline \multirow{4}{*}{ Variabel } & \multicolumn{4}{|c|}{ ROE } & \multicolumn{4}{|c|}{ PBV } \\
\hline & \multicolumn{2}{|c|}{ Model 1} & \multicolumn{2}{|c|}{ Model 2} & \multicolumn{2}{|c|}{ Model 3} & \multicolumn{2}{|c|}{ Model 4} \\
\hline & B & Stdr. & B & Stdr. & B & Stdr. & $\mathrm{B}$ & Stdr. \\
\hline & & Error & & Error & & Error & & Error \\
\hline MTLEV & $-0,169 * * *$ & 0,018 & & & $-0,047^{* * *}$ & 0,002 & & \\
\hline MLLEV & & & $-0,318^{* * *}$ & 0,039 & & & $-0,49^{* * *}$ & 0,005 \\
\hline MSLEV & & & $-0,119 * * *$ & 0,022 & & & $-0,046^{* * *}$ & 0,003 \\
\hline GROWTH & $0,150^{* * *}$ & 0,33 & $0,151^{* * *}$ & 0,032 & $0,009 * *$ & 0,004 & 0,009 ** & 0,004 \\
\hline SIZE & $1,894^{* * *}$ & 0,719 & $2,416^{* * *}$ & 0,713 & $0,684^{* * *}$ & 0,094 & $0,680 * * *$ & 0,096 \\
\hline Constant & $-10,184$ & 8,961 & $-16,390$ & 8,886 & $-4,738$ & 1,175 & $-4,665$ & 1,193 \\
\hline F Test & $43,953^{* * *}$ & & $39,541^{* * *}$ & & $166,384^{* * *}$ & & $126,440^{* * *}$ & \\
\hline $\mathrm{R}^{2}$ & & 0,290 & & 0,317 & & 0,599 & & 0,602 \\
\hline $\mathrm{N}$ & & 333 & & 333 & & 333 & & 333 \\
\hline
\end{tabular}

\section{Hypothesis:}

The first hypothesis in this study is that capital structure as measured by Market Total Leverage (MTLEV) has a significant negative effect on the company's financial performance as measured by Return On Equity (ROE). The results of the multiple regression test model 1 in Table 3 show that the $\mathrm{H} 1$ hypothesis is accepted. Then for the 
second hypothesis, namely the capital structure as measured by Market Long-Term Leverage (MLLEV) has a significant negative effect on the company's financial performance as measured by Return on Equity (ROE). The results of the multiple regression test model 2 in Table 3 show that the H2 hypothesis is accepted. The third hypothesis in this study is that capital structure as measured by Market Short-Term Leverage (MSLEV) has a significant negative effect on the company's financial performance as measured by Return On Equity (ROE). The results of the multiple regression test model 2 in Table 3 show that the hypothesis H3 is accepted. Furthermore, the fourth hypothesis in this study is that the capital structure as measured by Market Total Leverage (MTLEV) has a significant negative effect on the company's financial performance as measured by Price to Book Value (PBV). The results of the multiple regression test model 3 in Table 3 show that the hypothesis $\mathrm{H} 4$ is accepted.

The fifth hypothesis is that the capital structure measured by Market Long-Term Leverage (MLLEV) has a significant negative effect on the company's financial performance as measured by Price to Book Value (BPV). The results of the multiple regression test model 4 in Table 3 show that the hypothesis H5 is accepted. The sixth hypothesis in this study is that capital structure as measured by Market Short-Term Leverage (MSLEV) has a significant negative effect on the company's financial performance as measured by Price to Book Value (PBV). The results of the multiple regression test model 4 in Table 3 show that the hypothesis H6 is accepted. In addition to the results of hypothesis testing, Table 3 also shows that the control variables in the form of Growth and Size show a positive and significant effect on financial performance in the two research models.

\section{The Effect of Capital Structure on Company Financial Performance}

The results of the research show that the capital structures as measured by Market Total Leverage (MTLEV), Market Long-Term Leverage (MLLEV) and Market Short-Term Leverage (MSLEV) have negative and significant effect on the company's financial performance as measured by Return on Equity (ROE) and Price to Book Value (PBV). It can be interpreted that any increase in total debt, long-term debt and short-term debt based on market value will result in a decrease in ROE and PBV. Therefore debt has negative effect on company performance. The results of this study are in line with studies conducted by Adekunle \& Kajola (2010); Cai \& Zhang (2011); Le \& Phan (2017); Margaritis \& Psillaki (2010); Sadeghian et al. (2012); Vithessonthi \& Tongurai (2015) in which capital structure has negative and significant effect on company performance. However, the results of this study are not in line with the results of researchers Abidin et al. (2014); David \& Olorunfemi (2010); Detthamrong et al. (2017); Fosu (2013); Shyu (2013) states that capital structure has a positive effect on company performance.

Accordingly, this study supports the agency theory formulated Myers (1977) that debt is an efficient way to reduce conflict between shareholders and managers. On the other hand, the use of debt can create agency costs between shareholders and creditors. As debt increases, debt holders will need a higher interest rate to offset the risk of lower liquidity or investment. Therefore debt can have a negative effect on company performance. However, 
it is not in line with Jensen (1986) research which states that the high use of debt makes managers under pressure to invest in profitable projects to pay interest. Therefore, through reducing agency costs associated with managers and shareholders, debt can have a positive effect on company performance. Furthermore, the results of this study support the trade-off theory. According to Kraus \& Litzenberger (1973); Myers (1984) companies will exchange the costs of financial hardship and the benefits of tax savings from debt financing to create an optimal capital structure and increase corporate profits. The utilization of tax savings from debt is greater than the cost of bankruptcy, so the company's performance will increase. However, if the benefits of tax savings from debt are smaller than the cost of bankruptcy, increased debt will result in decreased company performance.

\section{CONCLUSION}

The results of this study indicate that the capital structure has negative and significant effect on the company's financial performance. Any increase in capital structure or increase in the level of debt will reduce the company's financial performance. The findings of this study support the agency theory that states that an increase in debt can lead to agency costs through an increase in the interest rate on debt by creditors. The research findings are also in line with the trade-off theory in which the company has entered a stage where additional debt provides less benefit than the costs that the company must bear.

The results of this study can be used to assist company managers to manage their capital structure so as to provide good performance. In this case, it reduces funding originating from debt so as to provide higher performance. Furthermore, the results of this study can help investors to invest, making the investors pay attention to the company's capital structure in selecting companies to invest. Investors are able to consider companies that do not have large debt, and do not invest in them as this will have impact on the small profits generated. Thus investors can consider the decision to invest. For future researcher, it is suggested to measure the capital structure using other ratios such as TDTA, LTDTA and STDTA as well as other company performance measurements such as Tobin's Q, EPS, NPM and others. The analysis period in this study is only five years, from 2014-2018. Therefore, it is hoped that further researchers can expand the period or extent of the observation.

\section{REFERENCES}

Abidin, Z., Yusniar, M. W., \& Ziyad, M. (2014). Pengaruh Struktur Modal, Kebijakan Dividen Dan Size Terhadap Nilai Perusahaan (Studi Pada Perusahaan Properti Di Bursa Efek Indonesia). Jurnal Wawasan Manajemen, 3(1), 91-102. doi:http://dx.doi.org/10.20527/jwm.v3i1.15.

Adekunle, O., \& Kajola, S. O. (2010). Capital structure and firm performance: Evidence from Nigeria. European Journal of Economics, Finance and Administrative Sciences, (25), 70-82. Retrieved from https://www.researchgate.net/publication/330997531. 
Cai, J., \& Zhang, Z. (2011). Leverage change, debt overhang, and stock prices. Journal of Corporate Finance, 17(3), 391-402. doi:https://doi.org/10.1016/j.jcorpfin.2010.12.003.

Cuong, N. T., \& Nguyen Thi, C. (2012). The Effect of Capital Structure on Firm Value for Vietnam's Seafood Processing Enterprises. International Research Journal of Finance and Economics, (89), 221-233. Retrieved from https://www.researchgate.net/publication/265808716.

David, D. F., \& Olorunfemi, S. (2010). Capital Structure and Corporate Performance in Nigeria Petroleum Industry: Panel Data Analysis. Journal of Mathematics and Statistics, 6(2), 168-173. doi:https://doi.org/10.3844/jmssp.2010.168.173.

Dawar, V. (2014). Agency theory, capital structure and firm performance: some Indian evidence. Managerial Finance, 40(12), 1190-1206. Retrieved from https://www.emerald.com/insight/content/doi/10.1108/MF-10-2013-0275.

Detthamrong, U., Chancharat, N., \& Vithessonthi, C. (2017). Corporate governance, capital structure and firm performance: Evidence from Thailand. Research in International Business and Finance, 42, 689-709. doi:https://doi.org/10.1016/j.ribaf.2017.07.011.

Fahmi, I. (2014). Analisis Laporan Keuangan (1 ed.). Bandung: Alfabeta.

Fischer, M. (2007). Saving and Investing. United State: AuthorHouse.

Fosu, S. (2013). Capital structure, product market competition and firm performance: Evidence from South Africa. The Quarterly Review of Economics and Finance, 53, 140151. doi:https://doi.org/10.1016/j.qref.2013.02.004.

Jensen, M. C. (1986). Agency Costs of Free Cash Flow, Corporate Finance, and Takeovers. American Economic Review, 76(2), 323-329. Retrieved from https://www.jstor.org/stable/1818789.

Jensen, M. C., \& Meckling, W. H. (1976). Theory of the firm: Managerial behavior, agency costs and ownership structure. Journal of Financial Economics, 3(4), 305-360. doi:https://doi.org/10.1016/0304-405X(76)90026-X.

Kieschnick, R., \& Moussawi, R. (2018). Firm age, corporate governance, and capital structure choices. Journal of Corporate Finance, 48, 597-614. doi:https://doi.org/10.1016/j.jcorpfin.2017.12.011.

Kraus, A., \& Litzenberger, R. H. (1973). A State-Preference Model of Optimal Financial Leverage. Joumal of Finance, 28(4), 911-922. doi:https://doi.org/10.1111/j.15406261.1973.tb01415.x.

Le, T. P. V., \& Phan, T. B. N. (2017). Capital Structure and Firm Performance : Emperical Evidence from A Small Transition Country. Reaerch In International Business and Finance, 42, 710-726. doi:https://doi.org/10.1016/j.ribaf.2017.07.012. 
Li, K., Niskanen, J., \& Niskanen, M. (2018). Capital structure and firm performance in European SMEs: Does credit risk make a difference? Managerial Finance, 45(5), 582601. doi:https://doi.org/10.1108/MF-01-2017-0018.

Margaritis, D., \& Psillaki, M. (2010). Capital structure, equity ownership and firm performance. Journal of Banking \& Finance, 34, 621-632. doi:https://doi.org/10.1016/j.jbankfin.2009.08.023.

Masa'deh, R. E., Alrowwad, A., Alkhalafat, F., Obeidat, B., \& Abualooush, s. h. (2018). The Role of Corporate Social Responsibility in Enhancing Firm Performance from the Perspective of IT Employees in Jordanian Banking Sector: The Mediating Effect of Transformational Leadership. Modern Applied Science, 12, 1-26. doi:https://doi.org/10.5539/mas.v12n7p1.

Mehran, H. (1992). Executive Incentive Plans, Corporate Control, and Capital Structure. Journal of Financial and Quantitative Analysis, 27(4), 539-560. doi: https://doi.org/10.2307/2331139.

Myers, S. C. (1977). Determinants of corporate borrowing. Journal of Financial Economics, 5, 147-175. doi:https://doi.org/10.1016/0304-405X(77)90015-0.

Myers, S. C. (1984). The Capital Structure Puzzle. The Journal of Finance, 39(3), 575-592. doi: https://doi.org/10.1111/j.1540-6261.1984.tb03646.x.

Park, K., \& Jang, S. (2013). Capital structure, free cash flow, diversification and firm performance: A holistic analysis. International Journal of Hospitality Management, 33, 51-63. doi:https://doi.org/10.1016/j.ijhm.2013.01.007.

Sadeghian, N. S., Latifi, M., Soroush, S., \& Aghabagher, Z. (2012). Debt Policy and Corporate Performance: Empirical Evidence from Tehran Stock Exchange Companies. International Journal of Economics and Finance, 4(11), 217-224. doi:https://doi.org/10.5539/ijef.v4n11p217.

Santos, J., \& Brito, L. (2012). Toward a Subjective Measurement Model for Firm Performance. BAR - Brazilian Administration Review, 9, 95-117. doi:https://doi.org/10.1590/S1807-76922012000500007 .

Shyu, J. (2013). Ownership structure, capital structure, and performance of group affiliation: Evidence from Taiwanese group-affiliated firms. Managerial Finance, 39(4), 404-420. doi: https://doi.org/10.1108/03074351311306210.

Vithessonthi, C., \& Tongurai, J. (2015). The effect of leverage on performance: Domestically-oriented versus internationally-oriented firms. Research in International Business and Finance, 34, 265-280. doi:https://doi.org/10.1016/j.ribaf.2015.02.016

Welch, I. (2004). Capital Structure and Stock Returns. Journal of Political Economy, 112, 106131. doi:http://dx.doi.org/10.1086/379933.

Welch, I. (2011). Two Common Problems in Capital Structure Research: The FinancialDebt-To-Asset Ratio and Issuing Activity Versus Leverage Changes. International Review of Finance, 11(1), 1-17. doi:http://dx.doi.org/10.1086/379933. 